\title{
Relative Usefulness of Indexing and Abstracting Services
}

Mr. Bonn is librarian, Technological Institute, Northwestern University.

TNEX and abstract services are, without 1 question, among the most important bibliographic devices available to the scientific library for tracking down currently published information. But they have their limitations and their individual peculiarities, their lapses and their lags. Whether or not these limitations make any difference to the library depends upon the actual use to which the indexes and abstracts are put by the library and its patrons.

The library staff of the Technological Institute, Northwestern University, has just completed a study of several standard current index and abstract services to find out just what can be expected from them as aids in preparing bibliographies of relatively current literature, and how they compare with each other in the subject fields of most interest to this library. Since the Technological Institute concerns itself almost entirely with chemistry, physics, and civil, chemical, electrical and mechanical engineering, the study was made using those services of most interest and use in these particular fields.

The publications studied were Engineering Index Service (on cards, daily), Industrial Arts Index, Chemical Abstracts, Science $A$ bstracts $A$ and $B$, British Abstracts and Nuclear Science Abstracts. No foreignlanguage index or abstract service was surveyed, mainly because none was available for the months during which the study was made. Since interest was centered in the services that are strictly indexing or abstracting in nature, no index or abstract section of any periodical was used.

The following questions were raised: ( I) How much of any desired bibliography can be obtained by using any one of the standard services? (2) How much of any bibliography would be missed by not using any one of the services? In other words, how many unique references are picked up by any one of the services? (3) How well are foreign sources covered? (4) How thoroughly does the service cover those journals it says it covers? (5) How completely does the service cover the journals in the field? (6) How promptly does the service do its job of indexing or abstracting? Or, put another way, what is the time lag between the date the original article appeared and the date the index reference or abstract appeared?

The study was made on a purely practical basis. That is, bibliographies were prepared on subjects in (or across) the fields of interest mentioned above using the index and abstract services listed, just as one would do in preparing any required bibliography for a course, for publication, or for further study. For control purposes only those indexes dated January through July, I949, were used, but (because of the unavoidable time lag in receiving these publications in this country, Science Abstracts $A$ and $B$ were available only through June while 
British Abstracts $A$ were available only through April ( $B$ through May).

Physics is represented by a bibliography of 44 references on electron accelerators, Bibliography $\mathrm{A}$ in the accompanying tables; chemistry, chemical engineering, and civil engineering are represented by a bibliography of 16 references on chlorine-dioxide and ozone usage in water treatment, Bibliography $B$ in the tables; electrical engineering by an 18 -item bibliography on telemetering, $\mathrm{C}$ in the tables; and mechanical engineering by a 38-item bibliography on supersonic aerodynamics, D in the tables. These subjects were suggested by persons actually needing bibliographies in these areas. The time limits were set by the library staff to bring the search to a halt somewhere while emphasizing currency. Since the bibliographies were prepared as a practical routine service, since rather narrow time limits were placed on their scope, and since only relative (rather than absolute) answers were wanted to the questions outlined, no great concern was felt because of the lengths of the resulting bibliographies. Nor was there any concern felt because the British publications were not yet available; under regular working conditions there is no choice but to take things as they come. Incidentally, British Abstracts $A$ for May arrived October IO, June arrived November 28, and July, December I4. British $A b$ stracts $B$ for June arrived September 9 (July arrived October 25); the July Science $A b$ stracts was received August $3 \mathrm{I}$.

Every reference found in any one of the services was searched for in each of the other services, not only in those dated during the seven-month period of the study but also in those dated one, two, and three months before January 1949, and in those dated August and September 1949, if they were available, in an attempt to make allowance for those services that are either more or less prompt than average, and allowing comparison to be made among the several services on the questions originally posed. The number of references found in each index or abstract service for each bibliography were then cross-tabulated against the six questions and appropriate tabulations were made for each service on each question.

For ease of comparison among the services, a rank-order listing was made of the several publications by ( $\mathrm{I}$ ) per cent of total references found in each bibliography, (2) per cent of unique references, (3) per cent of total foreign references found in each bibliography, (4) thoroughness of coverage of journals usually indexed, (5) completeness of coverage of journals in the fields concerned, and (6) speed of getting the references indexed; and, for completeness, a composite of the other six. These relative rank-order lists are given here as Figure I; the composite list is Figure 2.

The technique suggested can be used in making similar surveys in any subject field and for any group of index or abstract services. It has the advantages of being a thoroughly practical method using everyday operating procedures; of coming out with useful and usable bibliographies; of flexibility in selection of subject field, questions, and index services; of low, little, or no extra cost since the resulting bibliography will be or can be a part of the library's routine service function to a department or to a patron. This method will also give the librarian some idea of the usefulness of the current indexes and abstracts to the particular library in relation to the kind of reference work performed. The results reported are based on only one study. However, no appreciable variation in results has been found on such subjects as could be spot checked. The position of Chemical Abstracts in the field of physics is note- 


\section{FIGURE I}

Rank-order Lists of Index and Abstract Services for Each Bibliography

(I) By each service's portion of the total number of references found in each bibliography:

\begin{tabular}{|c|c|c|c|c|c|c|c|}
\hline \multicolumn{2}{|c|}{$\begin{array}{l}\text { Bibliography A } \\
\text { (Electron Acceler- } \\
\text { ators: Physics) }\end{array}$} & \multicolumn{2}{|c|}{$\begin{array}{l}\text { Bibliography B } \\
\text { (Chlorine-Dioxide and } \\
\text { Ozone Usage in Water } \\
\text { Treatment: Civil and } \\
\text { Chem. Engg. and Chem.) }\end{array}$} & \multicolumn{2}{|c|}{$\begin{array}{l}\text { Bibliography C } \\
\text { (Telemetering: } \\
\text { Elec. Engg.) }\end{array}$} & \multicolumn{2}{|c|}{$\begin{array}{l}\text { Bibliography D } \\
\text { (Supersonic Aero- } \\
\text { dynamics: Mech. } \\
\text { Engg.) }\end{array}$} \\
\hline $\begin{array}{l}\text { Nuclear Sci } \\
\text { Chem Abst } \\
\text { Ind Arts } \\
\text { Sci Ab B } \\
\text { Engg Ind } \\
\text { Sci Ab A }\end{array}$ & $\begin{array}{l}56.8 \\
45.4 \\
43.2 \\
36.3 \\
20.4 \\
15.9\end{array}$ & $\begin{array}{l}\text { Chem-Abst } \\
\text { Ind Arts } \\
\text { Engg Ind } \\
\text { Brit Abst }\end{array}$ & $\begin{array}{l}68.7 \\
37.5 \\
37.5 \\
25.0\end{array}$ & $\begin{array}{l}\text { Ind Arts } \\
\text { Engg Ind } \\
\text { Sci Ab B }\end{array}$ & $\begin{array}{l}83.3 \\
77.7 \\
38.8\end{array}$ & $\begin{array}{l}\text { Engg Ind } \\
\text { Ind Arts }\end{array}$ & $\begin{array}{l}73.6 \\
55 \cdot 3\end{array}$ \\
\hline
\end{tabular}

(2) By each service's unique references as a per cent of the total bibliography:

\begin{tabular}{lr|lr|lc|ll} 
Ind Arts & 15.9 & Chem Abst & 31.2 & Ind Arts & 22.2 & Engg Ind & 44.7 \\
Nuclear Sci & 11.3 & Brit Abst & 12.5 & Engg Ind & 16.6 & Ind Arts & 26.3 \\
Chem Abst & 9.1 & Engg Ind & 12.5 & Sci Ab B & 0 & & \\
Engg Ind & 2.3 & Ind Arts & 6.2 & & & & \\
Sci Ab B & 2.1 & & & & & & \\
Sci Ab A & 0 & & & & & &
\end{tabular}

(3) By each service's foreign references as a per cent of the total references in each bibliography:

\begin{tabular}{lr|lr|lr|lr} 
Nuclear Sci & 72.2 & Chem Abst & 80.0 & Engg Ind & 80.0 & Engg Ind & 92.3 \\
Chem Abst & 61.6 & Brit Abst & 40.0 & Ind Arts & 40.0 & Ind Arts & 7.7 \\
Sci Ab B & 38.8 & Engg Ind & 40.0 & Sci Ab B & 20.0 & & \\
Engg Ind & 11.1 & Ind Arts & 20.0 & & & & \\
Ind Arts & 5.5 & & & & & &
\end{tabular}

(4) By the thoroughness of the coverage of the journals usually indexed (numbers indicate references missed or not missed):

\begin{tabular}{lr|ll|ll|lr} 
Ind Arts & 6 & Ind Arts & 0 & Ind Arts & $\circ$ & Ind Arts & $\circ$ \\
Nuclear Sci & 15 & Chem Abst & 3 & Engg Ind & 4 & Engg Ind & Io \\
Sci Ab B & 21 & Brit Abst & 3 & Sci Ab B & 7 & & \\
Chdm Abst & 22 & Engg Ind & 3 & & & & \\
Engg Ind & 27 & & & & &
\end{tabular}

(5) By the completeness of the coverage of the journals in the field (numbers indicate references missed in journals not usually indexed):

\begin{tabular}{ll|lr|ll|lr} 
Chem Abst & 2 & Chem Abst & 2 & Engg Ind & 0 & Engg Ind & Ond \\
Nuclear Sci & 4 & Engg Ind & 7 & Ind Arts & 3 & Ind Arts & 17 \\
Sci Ab A & 6 & Brit Abst & 9 & Sci Ab B & 4 & & \\
Sci Ab B & 7 & Ind Arts & 10 & & & & \\
Engg Ind & 8 & & & & &
\end{tabular}

(6) By promptness of getting references indexed or abstracted (numbers indicate time lag in months between article and index dates):

\begin{tabular}{ll|lr|ll|ll}
\hline Ind Arts & 1.8 & Ind Arts & I.I & Ind Arts & I. I & Ind Arts & I.8 \\
Nuclear Sci & 3.9 & Engg Ind & 3.1 & Engg Ind & I.9 & Engg Ind & 5.7 \\
Engg Ind & 4.4 & Chem Abst & 7.8 & Sci Ab B & 5.3 & & \\
Sci Ab B & 5.9 & Brit Abst & 19.5 & & & \\
Chem Abst & 6.5 & & & & & \\
Sci Ab A & 7.0 & & & & & \\
\hline
\end{tabular}




\section{FIGURE II}

Composite rank-order list of index and abstract services for each bibliography determined by relative positions in the other six lists (numbers indicate composites of ranks in other six lists):

\begin{tabular}{|c|c|c|c|c|c|c|c|}
\hline \multicolumn{2}{|c|}{$\begin{array}{l}\text { Bibliography A } \\
\text { (Electron Acceler- } \\
\text { ators: Physics) }\end{array}$} & \multicolumn{2}{|c|}{$\begin{array}{l}\text { Bibliography B } \\
\text { (Chlorine-Dioxide and } \\
\text { Ozone Usage in Water } \\
\text { Treatment: Civil and } \\
\text { Chem. Engg. and Chem.) }\end{array}$} & \multicolumn{2}{|c|}{$\begin{array}{l}\text { Bibliography C } \\
\text { (Telemetering: } \\
\text { Elec. Engg.) }\end{array}$} & \multicolumn{2}{|c|}{$\begin{array}{c}\text { Bibliography D } \\
\text { (Supersonic Aero- } \\
\text { dynamics: Mech. } \\
\text { Engg.) }\end{array}$} \\
\hline $\begin{array}{l}\text { Nuclear Sci } \\
\text { Chem Abst } \\
\text { Ind Arts } \\
\text { Sci Ab B } \\
\text { Engg Ind } \\
\text { Sci Ab B }\end{array}$ & $\begin{array}{l}10 \\
17 \\
17 \\
23 \\
26 \\
33\end{array}$ & $\begin{array}{l}\text { Chem Abst } \\
\text { Engg Ind } \\
\text { Ind Arts } \\
\text { Brit Abst }\end{array}$ & $\begin{array}{r}9 \\
12 \\
14 \\
16\end{array}$ & $\begin{array}{l}\text { Ind Arts } \\
\text { Engg Ind } \\
\text { Sci Ab B }\end{array}$ & $\begin{array}{r}8 \\
10 \\
18\end{array}$ & $\begin{array}{l}\text { Engg Ind } \\
\text { Ind Arts }\end{array}$ & $\begin{array}{r}8 \\
10\end{array}$ \\
\hline
\end{tabular}

worthy in view of the importance of the literature of physics to the chemist, and of chemical literature to the physicist. ${ }^{1}$ Chemical Abstracts was found to be most nearly complete in coverage of the field, and second only to Nuclear Science Abstracts in per cent of total and foreign references.

A survey (touching in part on some of the topics covered in this study) of abstracting services has been in progress under the direction of the American Institute of Physics since October, $1948 .^{2}$ A preliminary report was made by Verner W. Clapp, chief assistant librarian of Congress, in a paper presented before the Serials Round Table at the I950 Midwinter Meeting of

1 Fussler, Herman. "Characteristics of the Research Literature Used by Chemists and Physicists in the United States." Library Quarterly, 19:19-35, January I 949, and 19:119.43, April 1949.

${ }_{2}$ Bray, Robert S. "The Physics Abstracting Study of the American Institute of Physics." Special Li braries, Vol. 40, No. 7, p. 248-50, September 1949. the American Library Association in Chicago. Clapp reported that the survey showed that 47 per cent of physics references were caught by Chemical Abstracts and that the average time lag between the dates of the original article and the abstract or index reference is either about four four months or more than a year. Comparable results were indicated in this study.

Unesco, Aslib, The Royal Society of London, and many other organizations are devoting more and more time and publication space to this very pressing problem of documentation of research, so there should be a number of valuable reports in forthcoming library literature. And each library can, in its own way and for its own special purposes, add its own bit to the general knowledge of this rapidly-growing field of investigation.

\section{Library of Congress Sesquicentennial}

The 15oth anniversary of the establishment of the Library of Congress on Apr. 24, 1800, will be commemorated with a Sesquicentennial Exhibition which opened with a reception on Monday, April 24, in the Great Hall of the Library. Many prominent librarians, government officials, members of Congress, educators and members of learned societies attended. The Exhibition, to be shown on the Ground Floor Gallery until December 31, will portray the progress of the Library during the last century and a half through changing displays of manuscripts, books, and photographs of the Library's collections. 